\title{
Automation and Structural Transformation in Developing Countries
}

\begin{abstract}
Technological change is likely to create a dual economy of automation-resistant and automation-susceptible sectors. Correspondingly, the labor force employed in automatable domains is pushed toward new activities - a dynamic that we liken to the classical Lewis model. We argue that the role of artificial intelligence and other advances is likely to be what we term a "robot reserve army," providing infinite supplies of artificial labor particularly in the agricultural and manufacturing sector. From this emerges a new pattern of structural transformation, as outlined in the previous chapter, with new distributional implications. We argue that tertiarization, income inequality, and wage stagnation, rather than, technological unemployment, are the key challenges of late development in the age of automation.
\end{abstract}

Keywords Robot reserve army • Lewis model 2.0 - Automatability • Employment $\cdot$ Distribution $\cdot$ Tertiarization

\subsection{Characteristics of Developing Countries}

Developing countries have special characteristics (vis-à-vis OECD countries): they tend to be labor-abundant and have higher rates of population growth than OECD countries. Large proportions of the population are often relatively unskilled and tertiary education is still comparatively

(C) The Author(s) 2020

L. Schlogl and A. Sumner, Disrupted Development and the Future of Inequality in the Age of Automation, Rethinking International Development series, https://doi.org/10.1007/978-3-030-30131-6_5 
limited even in upper middle-income developing countries. Compared to advanced high-income countries, they have a larger agricultural sector, and lower employment and value-added shares in industry and manufacturing, as well as a large informal service sector again not only in the world's poorest countries but even in upper middle-income countries. Production in such economies is less capital-intensive and productivity levels are thus lower than in high-income countries.

A number of developing countries have substantially shifted economic value-added activity from agriculture and resources to manufacturing and service sectors. For developing countries with such characteristics, a set of questions arises in the context of automation (that are different to the world's very poorest countries): What if industrial production can increasingly be carried out with minimal human labor input? What if robots in high-income countries start to compete with cheap labor? Is it plausible that there could be a disintegration of global value chains via "reshoring," i.e. the repatriation of formerly outsourced production to high-income countries? What if the service sector-where currently the largest share of labor is absorbed in many middle-income developing countries-goes through dramatic shifts of labor productivity, thanks to innovations in software and AI? Does automation exacerbate a muchdebated "middle-income trap" if it exists at all and thus impede catch-up development? Are there new sectors of economic activity emerging which promise decent employment opportunities for large populations rather than economic growth accompanied by weak employment growth? These questions point toward the importance of situating the role of technology in broader theories of economic development.

\subsection{Disrupted Development? The Role of Technological Change in Long-Run ECONOMIC DEVELOPMENT}

The neoclassical standard model of growth attributes a key role to technological change in long-run economic growth. In the Solow (1956) model, growth can be achieved either via an increase in the inputs of production, e.g. an expansion of the labor force or an increase in the capital intensity, or it can happen via greater efficiency in the combination of inputs that generates a larger output. The latter route is known as the dynamics of total factor productivity (TFP) and innovation in automation technologies is generally considered an important factor in raising the TFP. 
Summers (2013) considers a modification of the neoclassical two-factor production function in which output is created via both a complementary and a substitutive use of capital and labor (see for discussion Atkinson \& Bourguignon, 2014, p. xilx). Capital will be "deployed in these two uses to the point where their marginal productivity is the same" (Summers, 2013, p. 4) and a certain mix of capital and labor will result. Summers highlights three implications of labor-saving capital use: (i) production opportunities are augmented and output thus increases; (ii) wage rates fall; and (iii) returns to capital rise. Atkinson and Bourguignon thus argue:

We can therefore tell a story of macroeconomic development where initially the Solow model applies (...). A rising capital-labor ratio leads to rising wages and a falling rate of return. Beyond a certain point however (...) [labor-substituting capital use] begins to be positive. We then see further growth in the economy, as capital per head rises (...). There is no longer any gain to wage-earners, since they are increasingly being replaced by robots/automation. What is more, the capital share rises, independently of the elasticity of substitution. [The modified Solow model] highlights the central distributional dilemma: that the benefits from growth now increasingly accrue through rising profits. (Atkinson \& Bourguignon, 2014, p. xilx)

In line with the argument of a distribution dilemma, Roine and Waldenström $(2014$, p. 79$)$ - though they are skeptical of any "mechanical relationship between inequality and industrialization or technological change" - argue that: "the technological development starting in the 1970s constitute[s] the start of a shift, not from agriculture to industry as in Kuznets' original story, but from traditional industry to an ICTintensive sector that initially rewards a small part of the population, but eventually will spread, bringing inequality down."

There is thus a theoretical case that automation may be linked to income inequality and wage stagnation. Is there also a case for it leading to technological unemployment? The Solow model and its iterations suggest greater output (i.e. supply) due to automation which should translate into lower prices under conditions of competition. Lower prices in turn should lead to greater quantities demanded which necessitate more net employment of humans.

So, the net effect of using labor-saving technology could still be labor-increasing domestically. It may, however, not be if we took the Summers' model to its extreme: this would mean assuming a perfectly 
labor-saving production function where labor drops out entirely as a factor of production. In that case, output would be produced solely by nonhuman production factors.

Solow himself was skeptical of such a scenario. In a book on unemployment in the United States written in the 1960s, he noted that "rather spectacular scientific and engineering achievements" have led many "to the conclusion that there is a kind of revolution in progress, connected with the advance of automation" (Solow, 1964, p. 7). Yet, he doubted "that the clichés about automation and structural unemployment are very productive in analyzing the problem or bringing the remedy any closer" (ibid., p. 40) and he was particularly skeptical that automation calls for specific policy responses or a reorganization of the economic framework.

Of course, as noted above, not all labor is equally easy to substitute with machines. The dominant view has been that technology is skills-complementing or skills-biased (see Tinbergen, 1974, 1975). Empirically, models predicting a "skills premium" and rising market inequality due to automation are pervasive (see Acemoglu \& Autor, 2011; Autor, Katz, \& Kearney, 2004; Goldin \& Katz, 2007; Katz \& Autor, 1999; Katz \& Murphy, 2013). Others have argued, though, that technological change does not necessarily have to be skills-biased and inequality-increasing in every case (see Roine \& Waldenström, 2014).

The neoclassical growth model is a one-sector model and thus indifferent to the role of structural change in driving growth as Lewis (1954) intended, in his vision of economic development as a transfer of labor from a low-productivity, "traditional" sector to a higher productivity, "modern" sector. Herrendorf, Rogerson, and Valentinyi (2014) argue empirically that the sectoral composition of economic activity is key to understanding economic development. McMillan and Rodrik (2011, p. 1), also, in taking sectoral and aggregate labor productivity data empirically show that the transfer of labor and other inputs to higher productive activity is a driver of economic development, as Lewis hypothesized. However, they go on to note that structural change can in fact be growth-enhancing or growth-reducing, depending on the reallocation of that labor. ${ }^{2}$ Assuming technological labor-substitution, what can we say about potential implications for structural economic transformation, i.e. the reallocation of economic resources across sectors with different levels of productivity? 
The dual economy model of Lewis (1954) is based, as noted, on a traditional or subsistence sector and a modern sector, where in the former, there is a surplus of unproductive labor that is sustained by receiving an equal share of the total product for reasons of traditional/family-based values. Lewis argued that the driver of economic development was a sectoral movement of labor from the "traditional" or "subsistence" or "non-capitalist" sector (of low productivity, low wage, priced to average product not marginal product, and thus widespread disguised unemployment) to the "modern" or "capitalist" sector (of higher productivity, and where wages are set by productivity in the "subsistence sector."

A critical factor is the existence of surplus labor in the traditional sector. Because of this, wages are set just above subsistence across the whole economy, leading to the transfer of labor over time from the traditional to the modern sector, and the capture of labor productivity gains to capitalists as profits, as these are the source of growth via reinvestment. The floor for wages is institutionally set at subsistence. When surplus labor disappears, an integrated labor market and economy emerge, and wages will then start to rise.

The Lewis model was intended as a critique of the neoclassical approach in that labor is available to the modern or capitalist sector of an economy not in a perfectly elastic supply but upward sloping rather than flat, and with a distinction between surplus-producing labor and subsistence labor (the latter of which was a negligible source of net profits for reinvestment, which Lewis saw as the driver for growth).

Diao, McMillan, Rodrik, and Kennedy (2017, pp. 3-4) seek to link the structural dualism of Lewis with the neoclassical model, by arguing that the neoclassical model shows the growth process within the modern sector and the dual model shows the relationship between sectors. In short, the emergence of a modern sector with higher and competitively paid wages, and where profits are reinvested by capital owners, creates a pull force. This pull force attracts labor from the traditional sector. After a period of labor exchange via migration, an inter-sectoral equilibrium is reached, and wages are equalized between sectors.

Following Lewis' dual economy, we could divide up an economy into two sectors: an automation-prone sector (APS), consisting of jobs that are easy to perform by machines, and an automation-resistant sector (ARS), consisting of jobs that are hard to perform by machines (Fig. 5.1). ${ }^{3}$ The former would, for instance, include simple manual routine tasks like 
Economy with automatable tasks

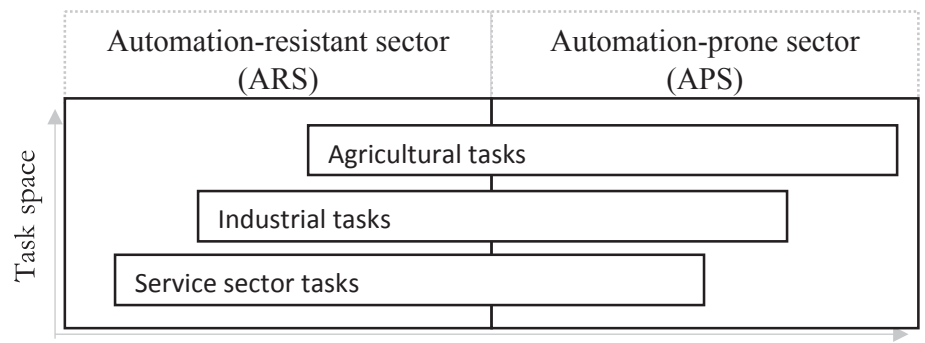

Distribution of $\operatorname{tasks}(\%)$

Partial technological replacement

\begin{tabular}{|l|l|l|}
\hline \multicolumn{2}{|l|}{ Agricultural tasks } & Automated \\
$\qquad$\begin{tabular}{|l|l|}
\hline Industrial tasks & Automated \\
\hline Service sector tasks & Automated \\
\hline
\end{tabular} \\
\hline
\end{tabular}

Full technological replacement

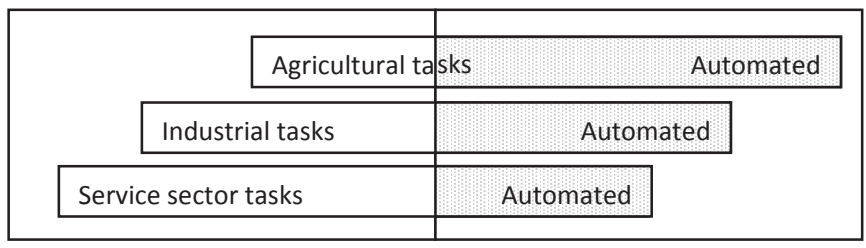

Change in technological frontier

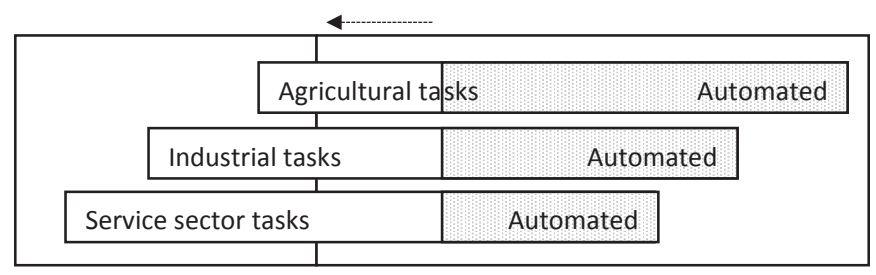

Fig. 5.1 Structural change in a "dual economy" defined by automatability. Source Authors' imagination 
lifting, drilling, and so forth and the latter would, for instance, include creative work involving face-to-face interaction.

With a view to the Lewis model of economic development, one could say that automation creates "unlimited supplies of artificial labor" in the APS. The increasing use of robots is thus equivalent to labor force growth in the APS. Arguably, the sheer capacity alone to build and deploy robots creates a new kind of "robot reserve army" in the APS, limiting the bargaining power and wages of labor in that sector. If automation is (technologically, legally, politically, and socially) feasible, the labor force will thus gradually be pushed from the APS into the ARS. There would be automation-driven structural change taking place.

In other words, automation itself constitutes a supply shock which shifts the labor supply curve in the APS to the right, and thus reduces the equilibrium wage in that sector (as well as in the ARS to the extent that labor can be absorbed in that sector). If the unit cost of automated production falls below the reservation wage of workers, a labor surplus is created. Automation thus frees up resources for the completion of non-automatable work. ${ }^{4}$ The surplus can either be absorbed by the ARS or, in case that is not possible, can lead to technological unemployment. Like in the Lewis model, the functional distribution of income changes in favor of capital owners.

Is there a "turning point"? In Lewis' standard model, a turning point is reached when surplus labor has fully migrated from the traditional or subsistence sector to the modern industrial sector, and wages start rising in the traditional sector due to an emerging labor shortage. In the model outlined here, there is, arguably, no such turning point. The supply of "artificial labor," i.e. automation, is genuinely unlimited, as it does not depend on demographic growth. In that case, human labor in the APS is fully displaced by machines and only an ARS remains. The ARS is itself, of course, not static but is defined by the technological frontier of the time. Technological innovation then gives rise to the shift of the frontier and thus reemergence of a new APS.

The question then becomes: What industries and tasks comprise the ARS and the APS, respectively? And is demand for the ARS large enough to allow full employment at decent wages? Regarding the first question, it would arguably be a mistake to suspect the location of the ARS primarily in newly emerging post-industrial sectors such as telecommunication or finance. Rather, the little amount of human work performed in modern agriculture is equally as automation-resistant by today's 
technological standards as resilient jobs in the industrial and the service sectors. ${ }^{5}$ The service sector is generally considered to contribute strongly to the ARS, as it involves plenty of nonroutine work involving social interactions. The current occupational structure of an economy reflects past (expectations of) automatability.

Regarding the second question, there could be a dilemma whereby a productivity boost in the APS (e.g. in agriculture) creates surplus labor, but the ARS (e.g. the industrial sector) is not able to fully absorb it. So-called premature deindustrialization could be due to such "Lewis 2.0" dynamics: workers might be moving to the service sector because the manufacturing sector has no demand for (unskilled) labor. It is fully imaginable from today's point of view that the industrial sector will at some point be absorbing an equally small number of workers as today's extractive and agricultural sectors are. A set of highly productive manufacturing clusters would then produce most of the physical goods there is demand for, while almost all human labor demand would remain in the service sector.

If that is the case, this would indicate that the digital revolution creates problems for analysis based on broad economic sectors such as "services": Castells (2010, p. 244) criticizes analysis based on sectors for three flaws: (i) the extreme heterogeneity of the service sector creates a "statistically obsolete category" which (ii) underestimates the "revolutionary nature of new information technologies" and (iii) the diversity of advanced societies and interdependence with the global economy from which different employment and occupational structures follow.

The historical productivity revolution in agriculture (or the "Green Revolution" in developing countries) shows how transformative and labor-saving technological change can be. In the British census of 1841, $22 \%$ of citizens were registered as being in agricultural employment whereas this number has dropped to below $1 \%$ in the present (Office for National Statistics, 2013). Agricultural shares in the developing world, though considerably higher, have also fallen rapidly (to an extent that Eastwood, Kirsten, \& Lipton [2007] have argued that developing countries underwent "premature agriculturalization").

Green revolutions have brought drastic productivity gains, allowing and incentivizing the reallocation of labor toward other-often hitherto nonexistent-economic activities and sectors. Many argue that technological leaps in agriculture allowed Western countries to escape a 
"Malthusian trap" which had kept living standards stagnant throughout most of preindustrial history (see Clark, 2008). Had there been policies to prevent the agricultural revolution because of job losses, the industrial revolution may not have unfolded in the same way. Historical structural change thus holds lessons, both for how hitherto unknown sectors can absorb labor from shrinking sectors, and what potential risks are involved in counteracting structural change.

The Industrial Revolution provides another point of reference for the digital transformation. Avent $(2017$, p. 162) argues that the digital revolution is set to repeat the experience of the Industrial Revolution which "bypassed the developing world for long decades." In Avent's view, integration into global supply chains which enabled rapid catch-up growth in the South ("export-led industrialization") was a transitory phenomenon that will soon be replaced by both "reshoring"-the repatriation of outsourced production-or will be limited to small high-tech clusters in developing economies (cf. Yusuf, 2017). Such clusters might not create the large-scale job opportunities that broad-based industrial activity provided historically. According to Avent (2017, p. 163), the digital revolution will thus "make it more difficult in the future for poor countries to repeat the performance of the past twenty years. Once again, rich economies will enjoy a near-monopoly on the sorts of social capital required to generate a rich-world income" such as democracy, property rights, and accountable governance. One could call this the threat of a "disruption" of the catch-up development process. ${ }^{6}$

\subsection{The Fourth Industrial Reserve Army}

What can be said about the characteristics of a labor surplus? Lewis (1954), in his seminal text on unlimited supplies of labor, saw himself working "in the classical tradition" of Karl Marx and Adam Smith.

In Das Kapital, Karl Marx (2012 [1867]) posited that there is a "progressive production of a relative surplus population or Industrial Reserve Army" (ibid., p. 274) as both a condition and an outcome of the capitalist mode of production. ${ }^{7}$ Overpopulation, in Marx' view, provides a "mass of human material always ready for exploitation" (ibid., p. 276), holding the wages of the active labor force in check and thus feeding a process of capital accumulation. Throughout this process of accumulation, the productiveness of labor constantly expands with growing employment of machinery. This accelerating capital accumulation 
process leads, in Marx' view, to a "constant transformation of a part of the laboring population into unemployed or half-employed hands" (ibid., p. 278), i.e. a surplus population relative to the labor demand of industry (rather than an absolute overpopulation in a Malthusian sense).

Marx had a strong interest in the relationship of technology and labor in the production process, and he specifically points to the "automatic factories" where "only a very small number continue to find employment," while the majority who get laid off form a "floating surplus population" (ibid., p. 281). He speaks of workers being degraded to the estranging status of an "appendage of a machine" (ibid.) and, in Das Kapital, Marx sees the process of technology-driven capitalistic development as an "accumulation of misery" (ibid.). This line of argument is stark techno-pessimism.

Although Lewis' conception of surplus labor as a population defined "relatively to capital and natural resources" sounds Marxian (and also Malthusian), there are some differences in that Lewis really means disguised rather than actual unemployment. In other words, Lewis' surplus population receive wages and, moreover, these wages exceed their marginal productivity (cf. Lewis, 1954, pp. 14lf.). ${ }^{8}$ Marx (2012, p. 283), on the other hand, distinguished multiple forms of surplus labor: a "floating" form where workers have to constantly change employers; a "latent" form of precarious agricultural (under)employment; a "stagnant" form characterized by irregular employment at minimal wages; and a "pauperist form" which is made up of criminals and "dangerous classes." Lewis' conception of surplus labor thus resembles that of Marx' latent surplus, whereas he explicitly disagrees with the notion of productivity-driven labor surplus:

"Marx offered a third source of labor to add to the reserve army, namely the unemployment generated by increasing efficiency. (...) Nowadays we reject this argument on empirical grounds. It is clear that the effect of capital accumulation in the past has been to reduce the size of the reserve army, and not to increase it, so we have lost interest in arguments about what is 'theoretically' possible" (Lewis, 1954, p. 145).

Lewis was thus a technological optimist. Indeed, if the industrialized/urban/capitalistic sector in his model is also assumed to produce surplus labor, the model of labor exchange would arguably break down.

Marx and Lewis concur that the reserve army is central to capital accumulation in modern capitalism. Lewis (1954, p. 145), though, 
is much more sanguine about this process as he sees the "expansion of new industries or new employment opportunities without any shortage of unskilled labor." When in Sect. 5.2, we proposed to understand automation along the lines of a "Lewis 2.0 model" the idea was thus to incorporate elements of both Marxian and Lewisian thinking: in light of current technological development, we may not want to reject Marx' views on automation “on empirical grounds” quite as categorically as Lewis did-even if the impact of reserve army dynamics are more likely wage pressures in the APS rather than the drastic employment-destroying effects of the "automatic factory" that Marx had in mind.

Lewis, on the other hand, may have been right in considering surplus labor primarily as an engine of structural change within a dualistic economy framework. Labor that is "set free" may get permanently absorbed in the ARS. The question then is whether such modern-day automation-driven structural change has equally benign effects (particularly under conditions of global competition and an international division of labor), as Lewis assumed traditional structural change to have, in labor-abundant Asian developing countries. ${ }^{9}$

\subsection{Existing Empirical Forecasts of the Employment EfFects of Automation}

It is an empirical question if and in what sectors automation reduces labor demand. As was discussed, automation could reduce employment if the ARS has a low demand for labor. But if productivity gains lead to lower prices and thus higher quantities demanded, net job effects could be positive. Furthermore, the demand for new labor-intensive work could rise as the cost of labor falls relative to capital. Many would argue that the very problem of developing countries is that there is too little, rather than too much, automation and thus lower labor productivity.

Table 5.1 presents a further layer to the "Lewis 2.0" model of economic development in an analytical framework to consider automation effects on employment within the two-sector model presented earlier. One could speak of an adaptable and a non-adaptable labor force (defined, for instance, by the skills level).

One could then hypothesize the existence of two opposing forces in automation-driven structural change in the developing world: (i) labor 
Table 5.1 The labor dynamics of automation in a dual economy

\begin{tabular}{llll}
\hline Technology & Labor & Response & Outcome \\
\hline Complementary & Adapted & Keep/hire & Structural stability \\
Substitutive & Adaptable & Retrain/switch task & Structural change \\
& Non-adaptable & Lay off & \\
\hline
\end{tabular}

Source Authors' imagination

is cheaper than in high-income countries, thus more competitive visà-vis machines, and there is thus less of an incentive to automate; and (ii) conversely, given widespread low-skilled manual routine work, work tasks that are prevalent in developing countries are easier to automate from a technological viewpoint. In other words, the APS will likely be larger in developing countries. Considering the taxonomy that was proposed earlier, this means that automation is arguably more technologically but less economically feasible.

Empirical estimates and forecasts of the potential impact of automation across the world are presented in Table 5.2 (the table is nonexhaustive). It is immediately evident from the studies in Table 5.2 that there is no consensus on jobs impacts and substantial variation in current estimates.

Estimates range from alarming scenarios, according to which there is a " $50 \%$ chance of AI outperforming humans in all tasks within 45 years" (Grace, Salvatier, Dafoe, Zhang, \& Evans, 2017, emphasis added), on the one hand, to contrasting claims of there being "no evidence that automation leads to joblessness" (Mishel \& Bivens, 2017, p. 1), and the sarcastic recommendation that "everyone should take a deep breath" (Atkinson \& Wu, 2017, p. 23).

The seminal study in the recent automation literature is that of Frey and Osborne (2013) for the United States, and subsequent studies have reproduced and refined their methodology. They conclude that almost half of the US employment is "at risk." In contrast, Arntz, Gregory, and Zierahn (2016) occupies a middle ground in terms of optimism. The authors argue with some plausibility for a "task-based" rather than aninevitably oversimplified- "occupation-based" approach to estimating automatability risk. Arntz et al. draw on data from an international survey of adult skills conducted across OECD countries which contains data 
Table 5.2 Estimates of the employment impact of automation

\begin{tabular}{|c|c|c|}
\hline Authors & Region & Findings \\
\hline \multicolumn{3}{|l|}{ Studies of OECD countries } \\
\hline Frey and Osborne (2013) & US & $\begin{array}{l}\text { " } 47 \text { percent of total US employment is at } \\
\text { risk" (ibid., p. 1) }\end{array}$ \\
\hline Barany and Siegel (2014) & US & ICTs substitute middle-skill occupations \\
\hline $\begin{array}{l}\text { Acemoglu and Restrepo } \\
(2015)\end{array}$ & $\mathrm{n} / \mathrm{a}$ & $\begin{array}{l}\text { "Automation, by reducing wages relative } \\
\text { to the rental rate of capital, encourages the } \\
\text { creation of new labor-intensive tasks" (ibid., } \\
\text { p. } 41 \text { ) }\end{array}$ \\
\hline Arntz et al. (2016) & OECD & $\begin{array}{l}9 \% \text { of jobs automatable but "jobs at risk" } \\
\text { may not translate into employment loss; } \\
\text { large negative job effects "unlikely" }\end{array}$ \\
\hline Bessen (2016) & US & $\begin{array}{l}\text { During } 1984-2007 \text { computer use was asso- } \\
\text { ciated with a } 3 \% \text { average annual job loss in } \\
\text { manufacturing but a } 1 \% \text { increase elsewhere }\end{array}$ \\
\hline $\begin{array}{l}\text { Executive Office of the } \\
\text { President of the United } \\
\text { States }(2016)\end{array}$ & US & $\begin{array}{l}\text { "Economy has repeatedly proven itself } \\
\text { capable of handling this scale of change," } \\
\text { but jobs at risk "concentrated among } \\
\text { lower-paid, lower skilled, and less-educated } \\
\text { workers" (ibid., p. 2) }\end{array}$ \\
\hline $\begin{array}{l}\text { Acemoglu and Restrepo } \\
(2017)\end{array}$ & US & $\begin{array}{l}\text { "One additional robot per thousand work- } \\
\text { ers (...) reduces aggregate employment to } \\
\text { population ratio by } 0.34 \text { percentage points } \\
\text { and aggregate wages by } 0.5 \text { percent" (ibid., } \\
\text { p. } 36 \text { ) }\end{array}$ \\
\hline Atkinson and $\mathrm{Wu}$ (2017) & US & $\begin{array}{l}\text { Labor market disruption occurring at its } \\
\text { lowest rate since the Civil War }\end{array}$ \\
\hline IMF (2017) & $\begin{array}{l}\text { Advanced } \\
\text { economies }\end{array}$ & $\begin{array}{l}\text { Technological progress "explains about half } \\
\text { the overall decline [of the labor income } \\
\text { share] in advanced economies, with a larger } \\
\text { negative impact on the earnings of mid- } \\
\text { dle-skilled workers" }\end{array}$ \\
\hline Mishel and Bivens (2017) & US & $\begin{array}{l}\text { No evidence that automation leads to job- } \\
\text { lessness or inequality }\end{array}$ \\
\hline PWC (2017) & OECD & $\begin{array}{l}\text { Automation could replace } 38 \% \text { jobs in the } \\
\text { United States, } 35 \% \text { in Germany, } 30 \% \text { in the } \\
\text { UK, and } 21 \% \text { in Japan by early } 2030 \text { s }\end{array}$ \\
\hline \multicolumn{3}{|l|}{$\begin{array}{l}\text { Studies of developing } \\
\text { countries }\end{array}$} \\
\hline Chandy (2017) & $\begin{array}{l}\text { Developing } \\
\text { countries }\end{array}$ & $\begin{array}{l}\text { "Automation is likely to replace jobs even } \\
\text { faster in developing countries than in indus- } \\
\text { trial ones" (ibid., p. 15) }\end{array}$ \\
\hline
\end{tabular}


Table 5.2 (continued)

\begin{tabular}{|c|c|c|}
\hline Authors & Region & Findings \\
\hline Chang and Huynh (2016) & $\begin{array}{l}\text { South East } \\
\text { Asia }\end{array}$ & $\begin{array}{l}56 \% \text { of jobs are at high risk of automation } \\
\text { in Association of Southeast Asian Nations } \\
\text { (ASEAN) countries }\end{array}$ \\
\hline Frey et al. (2016) & $\begin{array}{l}\text { Developing } \\
\text { countries }\end{array}$ & $\begin{array}{l}\text { "Developing countries are highly suscepti- } \\
\text { ble to the expanding scope of automation" } \\
\text { (ibid., p. 18) }\end{array}$ \\
\hline Frey and Rahbari (2016) & $\begin{array}{l}\text { OECD and } \\
\text { Ethiopia, } \\
\text { India and } \\
\text { China }\end{array}$ & $\begin{array}{l}\text { China will lose } 77 \% \text { of jobs to automation, } \\
\text { India } 69 \% \text {, Ethiopia } 85 \% \text {, and OECD aver- } \\
\text { age } 57 \% \text { jobs lost }\end{array}$ \\
\hline World Bank (2016) & $\begin{array}{l}\text { Developing } \\
\text { Countries }\end{array}$ & $\begin{array}{l}\text { Two-thirds of all jobs susceptible to } \\
\text { automation ( } 1.8 \text { bn jobs), but the effects } \\
\text { are moderated by lower wages and slower } \\
\text { technology adoption }\end{array}$ \\
\hline Avent (2017) & $\begin{array}{l}\text { Developing } \\
\text { Countries }\end{array}$ & $\begin{array}{l}\text { "New technology seems to be making life } \\
\text { harder for the emerging world" (ibid., p. } \\
\text { 171) }\end{array}$ \\
\hline $\begin{array}{l}\text { World Economic Forum } \\
(2017)\end{array}$ & Africa & $\begin{array}{l}41 \% \text { of all work activities in South Africa } \\
\text { susceptible to automation, } 44 \% \text { in Ethiopia, } \\
46 \% \text { in Nigeria, and } 52 \% \text { in Kenya }\end{array}$ \\
\hline $\operatorname{ADB}(2018)$ & Asia & $\begin{array}{l}\text { In the period of } 2005-2015 \text { in } 12 \text { Asian } \\
\text { economies there were } 101 \mathrm{~m} \text { job losses } \\
\text { per annum due to "modern machine tools } \\
\text { and ICT equipment" which were offset by } \\
134 \mathrm{~m} \text { jobs created due to higher demand } \\
\text { for goods and services (ibid., pp. } 77-78 \text { ) }\end{array}$ \\
\hline \multicolumn{3}{|l|}{ Global studies } \\
\hline Grace et al. (2017) & Global & $\begin{array}{l}50 \% \text { chance of AI outperforming humans } \\
\text { in all tasks in } 45 \text { years and of automating all } \\
\text { human jobs in } 120 \text { years }\end{array}$ \\
\hline $\begin{array}{l}\text { McKinsey Global Institute } \\
(2017 \mathrm{a})\end{array}$ & Global & $\begin{array}{l}\text { Using existing technologies, around } \\
\text { two-thirds of occupations could have one- } \\
\text { third of their constitutive tasks automated }\end{array}$ \\
\hline
\end{tabular}

Source Sources cited

on the tasks performed for each type of job. The authors use these data to impute a score of automatability, as well as the size of the population at "high risk" of automation. Interestingly, Russia's occupational structure is deemed least automatable of the 21 countries considered, whereas Germany and Austria top the rank. Put differently, the country with the 
lowest gross domestic product (GDP) per capita (and per worker) in the data set considered by Arntz et al. (2016) shows the highest resilience to automation. Generally, there is no consistent relationship with GDP per capita and their score of automatability, though, in this OECD data set (which is based on a selection of structurally similar economies).

The McKinsey Global Institute (2017b) provides estimates of employment that is susceptible to automation for $\mathbf{5 2}$ countries, which is the most comprehensive global data set we know of. Overall, McKinsey is considerably more pessimistic with their estimates of mean automatability, being on average 10 percentage points above that of Arntz et al. Their estimates are more pessimistic in every country and considerably more pessimistic specifically regarding non-OECD countries. ${ }^{10}$ Across Western OECD countries only, the estimates of Arntz et al. and McKinsey are, in fact, closely aligned $\left(r^{2}=0.5\right)$. Their automatability estimates of industrialized economies such as Russia, Korea, and Japan, though, differ significantly, with McKinsey being considerably more pessimistic.

Another recent global estimate comes from the World Bank (2016) who provide data for 40 countries and are yet more pessimistic, with average estimates lying 20 percentage points above the McKinsey estimate. The overlap of country coverage between the World Bank and the McKinsey estimates is small (nine countries); among those, the shared variance is relatively low at about $12 \%$ (Table 5.3 shows selected countries). In addition to automatability estimates, the World Bank also

Table 5.3 Estimates of the proportion of employment that is automatable in selected countries

\begin{tabular}{lcc}
\hline & $M G I(2017 c)(\%)$ & World Bank (2016) (\%) \\
\hline Argentina & 48 & 65 \\
China & 51 & 77 \\
Costa Rica & 52 & 68 \\
Ethiopia & 50 & 85 \\
India & 52 & 69 \\
Malaysia & 51 & 68 \\
Nigeria & 46 & 65 \\
South Africa & 41 & 67 \\
Thailand & 55 & 72 \\
\hline
\end{tabular}


provides adjusted estimates which take into account the different speeds of technology diffusion across countries.

In the next section, we explore the McKinsey Global Institute (2017b) and World Bank (2016) data in more detail. ${ }^{11}$

\subsection{Empirical Patterns of Automatability AND ECONOMIC DEVELOPMENT}

Instead of focusing on the levels of automatability per se, which remains fairly contentious we next discuss the relationship of automatability and economic development. ${ }^{12}$

The first observation to make (and one that was also made by Frey, Osborne, \& Holmes, 2016) is that automatability estimates show a relationship with the level of GNI per capita across countries in global comparison (Fig. 5.2). Both sets of estimates are highly significantly $(p<0.01)$ negatively correlated with gross national income (GNI) per capita. Thus, the richer an economy, the less automatable the labor force. That said, McKinsey's estimates range from a minimum of $41 \%$ to a maximum of $56 \%$ and the World Bank's from 55 to $85 \%$, so even the most resilient countries could still see significant labor market disruption.

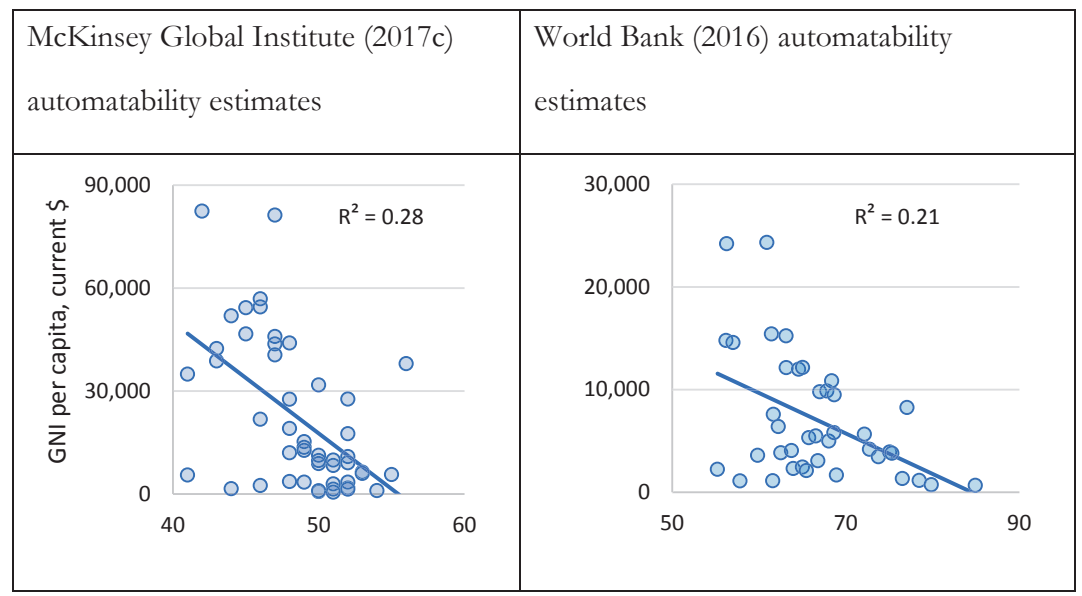

Fig. 5.2 The level of economic development and the share of employment susceptible to automation. Source Authors' estimates based on sources cited 
It is interesting to note that the McKinsey Global Institute assigns the lowest automatability estimates to Kuwait and South Africa, the former an entirely oil-fueled Organization of the Petroleum Exporting Countries (OPEC) economy with practically no unemployment, and the latter having one of the highest unemployment rates and most segregated labor markets in the world. Overall, the median estimates of the McKinsey Global Institute for HICs $(n=27)$ is 47 , whereas the median for low-income countries (LICs) and lower middle-income countries (LMICs) $(n=13)$ is 51 .

It is worth at this point considering the structural characteristics of economies. Figure 5.3 reproduces the familiar cross-country pattern across three sectors, showing that rich countries generally have very low levels of employment in agriculture and high levels of service sector employment, with the reverse being the case for developing countries. The industry share of employment is uncorrelated with GNI per capita $(p>0.05)$ from a cross-country perspective.

Given this overall structural pattern, what then is the relationship between automatability and sectoral characteristics? Figure 5.4 shows that the pattern is similar, though somewhat less pronounced, to the pattern of GNI per capita and automatability. The service sector share, in particular, is a strong predictor of both McKinsey's and the World Bank's automatability estimates. The more agrarian an economy is, the larger the population performing tasks that machines could theoretically perform.

We can thus say, assuming the automatability estimates are reasonable, that the labor force of more service sector-based, richer economies tends to be less replaceable compared to more agriculture-based, poorer economies. This pattern is intuitive and is explained by the complexity and creativity of service-sector work and the amount of face-to-face human interaction involved in it. If we break down the relationship of sectoral employment by level of GNI per capita (Fig. 5.5), the above-mentioned pattern largely holds. Among HICs, there is no relationship between agriculture and automatability simply because there is almost no employment in agriculture. Industrial work is more automatable and service-sector work less automatable across both country groupings, so the level of economic development does not moderate that sectoral relationship. ${ }^{13}$

Generally, we can say the APS is (much) larger in countries with lower income per capita. If countries have to decide how to reallocate employment during structural change and the described cross-country pattern 
Agriculture

$R^{2}=0.4206$

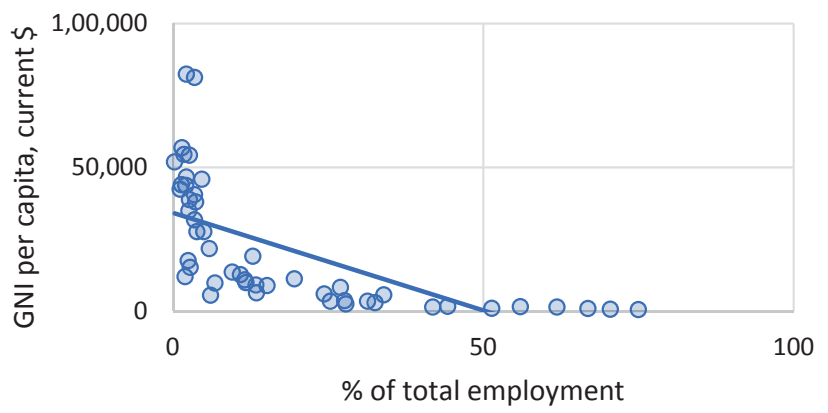

Industry

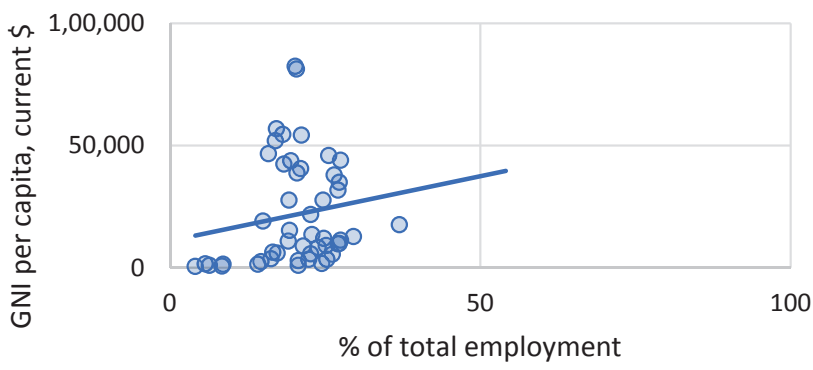

Services $\quad R^{2}=0.5151$

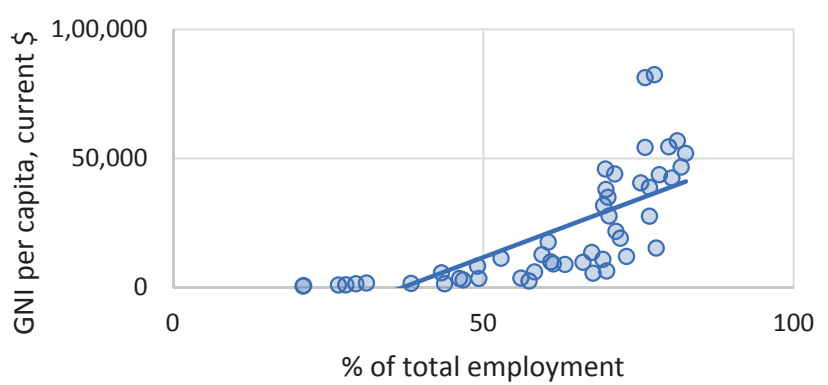

Fig. 5.3 Employment by sectors and GNI per capita (2016 or most recent data). Source Authors' estimates based on World Bank [2016] 


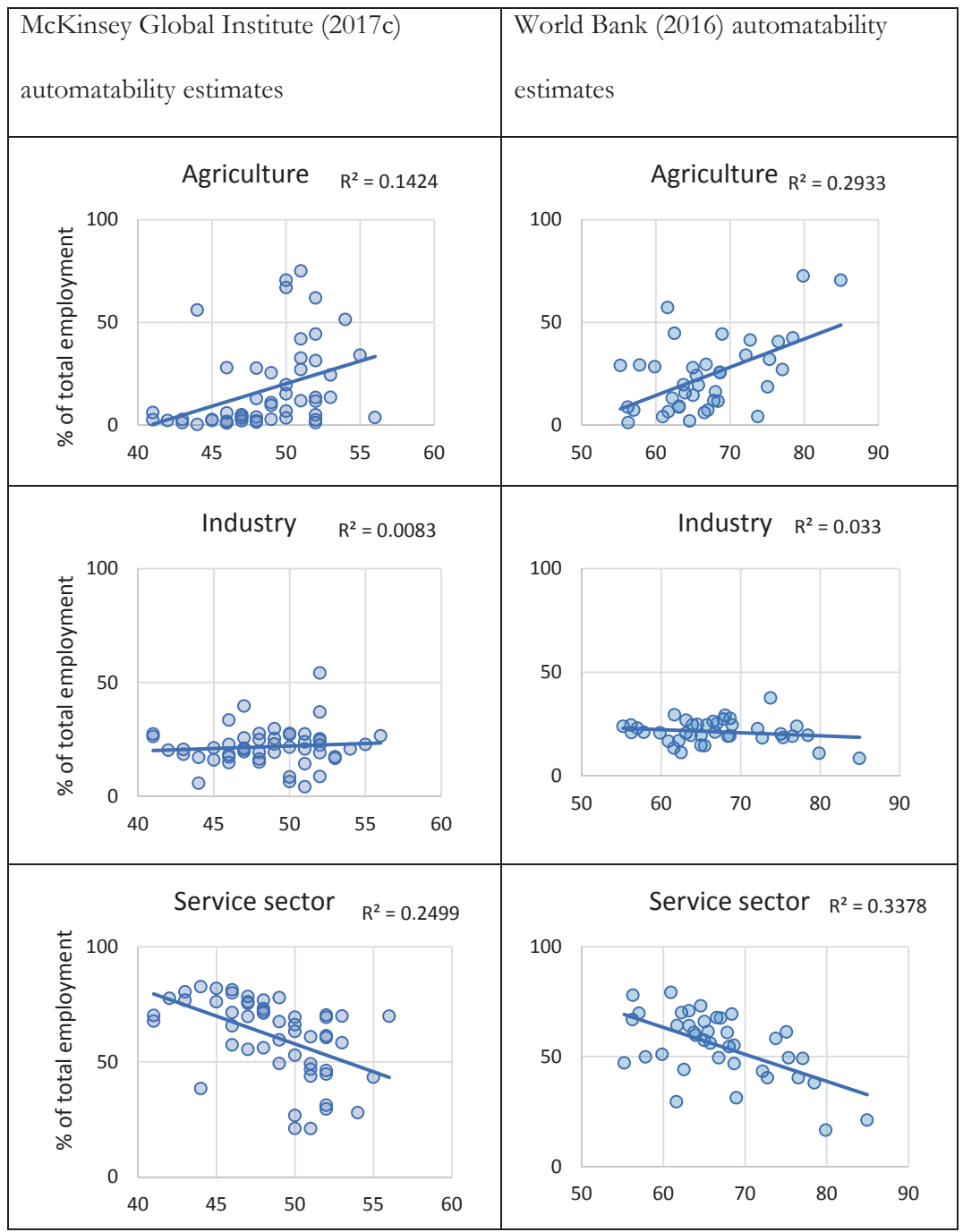

Fig. 5.4 Automatability and share of employment by sectors, 2016. Source Authors' estimates based on sources cited 


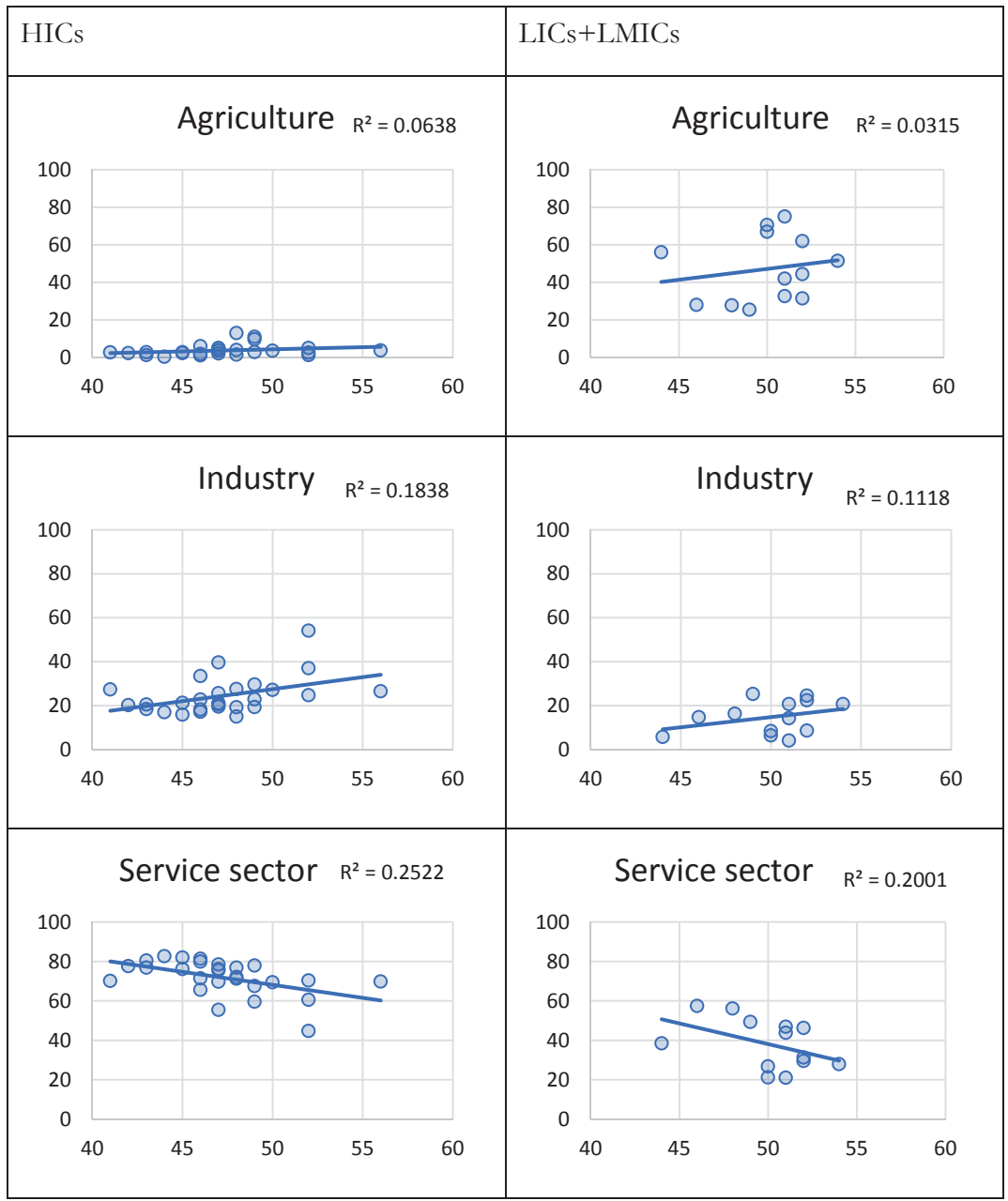

Fig. 5.5 McKinsey Global Institute's automatability estimates and employment across economic sectors by income group. Source Authors' calculations based on McKinsey Global Institute [2017b] and World Bank [2016] 


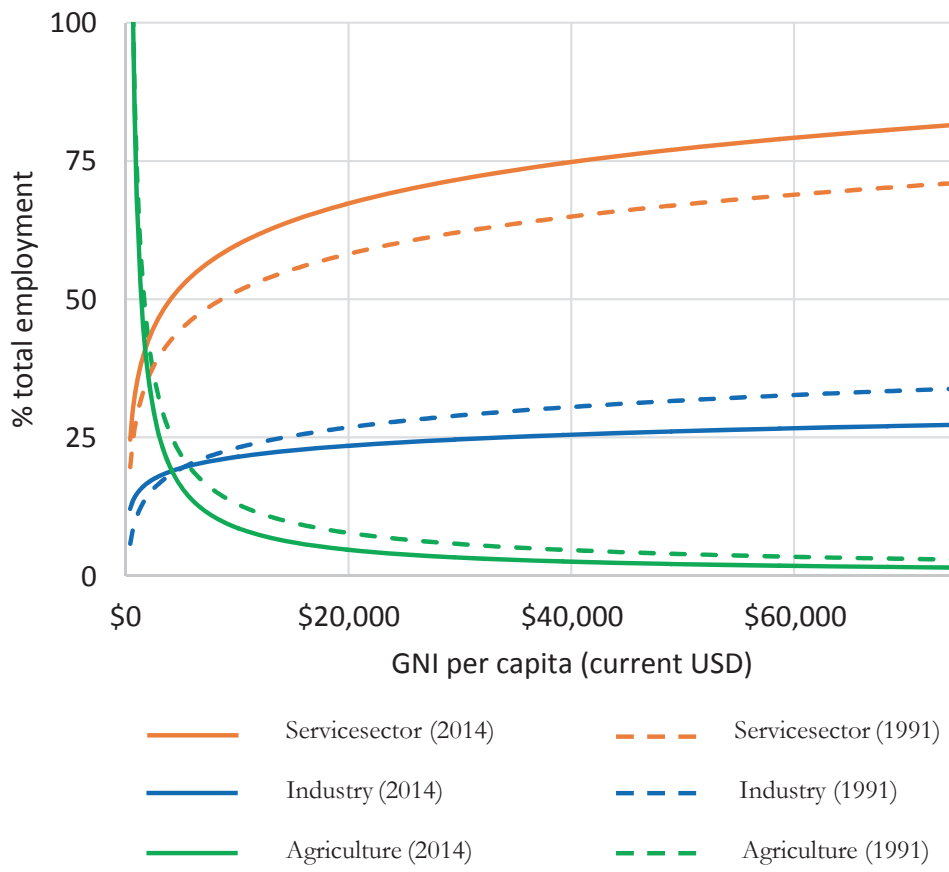

Fig. 5.6 Economic development and sectoral employment shares across countries (fitted lines): 1991 and 2014. Source Authors' estimates based on World Bank [2018] data

allows any inference about country-level developments over time, an increase in service-sector employment would suggest itself as the only future-proof employment growth model. In HICs, it would suggest structural change away from industrial work and in developing countries away from agriculture.

What does this mean for the future of economic development and structural transformation? Holding all else constant, sectoral differences in the replaceability of labor will sustain a pressure for both further deindustrialization and deagriculturalization. This is not a new phenomenon: in fact, the cross-country pattern of sectoral employment shares shown earlier in Fig. 5.4 and reproduced in Fig. 5.6 to compare 1991 
and 2014 (fitted lines) shows a surprising degree of continuity over time. What appears to be happening, though, is an expansion of servicesector employment in the richest countries, and a reduction in the share of industrial work compared to the early nineties (this pattern is corroborated by Wood, 2017). In line with this, Chandy (2017, p. 14) speculates that "China may be one of the last countries to ride the wave of industrialization to prosperity." Generally, most of the global cross-country variability of employment shares is found toward the low end of the GNI per capita, whereas countries above a per capita GNI of 20,000 look structurally very similar, i.e. are highly service-based and thus face lower automatability. In general, it is only in the poorest countries that a considerable proportion of labor is in agriculture. However, even in middle-income developing countries such as Indonesia and Thailand, a third of the labor force remains in agriculture. Agriculture employs only a few percent of labor force in wealthy countries. This suggests that in contrast to OECD countries, many jobs in developing countries have likely been automatable for a long time.

\section{Notes}

1. Roine and Waldenström (2014) suggest a new Kuznets curve based on technological developments starting not a sectoral shift of agriculture to industry but a shift from traditional industry to technologically intensive industry. If a given technology makes skilled workers more productive and there is an increase in the relative demand for those workers, the rewards accrue to a small proportion of the population who are skilled workers. Based on Tinbergen's (1974, 1975) hypothesis that the returns to skills are a competition between education and technology, the supply of skilled workers then determines whether or not their wages rise. Roine and Waldenström argue that the drivers of the Kuznets downturn are political and exogenous shocks.

2. McMillan and Rodrik show how structural change had been growthenhancing in Asia because labor has transferred from low to higher productivity sectors. However, the converse is the case for sub-Saharan Africa and Latin America because labor has been transferred from higher to lower productivity sectors and this has reduced growth rates. They find that countries with a large share of exports in natural resources tend to experience growth-reducing structural transformation and, even if they have higher productivity, cannot absorb surplus labor from agriculture. 
3. This of course has resonance with Baumol (1967) who in a similar fashion divided up the economy into "technologically progressive" and "technologically non-progressive" activities. In the former, productivity-driving, sector "labor is primarily an instrument (...) while in other $(\ldots)$ labor is itself the end product" (ibid., p. 416). One issue is our approach implies a somewhat linear view of structural change that does not take into account the servicification of manufacturing and therefore an overlap between APS and ARS. This would also mean for Table 5.1 that even complementarity could drive structural change in that the services that digitization adds to manufacturing could drive industrialization.

4. Baumol's "unbalanced growth" model similarly envisaged a labor transition from one to the other sector and aggregate stagnant labor productivity as a result (Baumol, 1967; Baumol, Blackman, \& Wolff, 1985; see also Ngai \& Pissarides, 2017 for a contemporary iteration of the model). Autor and Dorn (2013), based on a spatial equilibrium model, posit a reallocation of low-skill labor into service occupations (a phenomenon they call "employment polarization" which then entails wage polarization).

5. Of course, both the existence of agricultural subsidies and trade of agricultural products makes an assessment more difficult. Without subsidies, the sector might employ even fewer people. Conversely, OECD countries are not self-sufficient and depend on labor in foreign countries to produce food for export to OECD countries.

6. The concept of disruption or disruptive innovation goes back to Christensen's (1997) book The Innovator's Dilemma. In it, he describes how emerging technologies developed by small challengers can threaten dominant and generally well-managed businesses. Disruption generally means an unanticipated, revolutionary transformation that impacts an established market. Such disruption could happen to global value chains and thus the export-oriented industrialization development model.

7. One issue Marx would have raised is the ownership of the intellectual property that drives robots, and the reinvestment of related rents.

8. For Lewis, wages are set at subsistence level, but since the marginal productivity of surplus workers is assumed to be (close to) zero, any wage they get exceeds their marginal contribution: “...large sectors of the economy where the marginal productivity of labor is negligible, zero, or even negative"-i.e. the subsistence sectors (1954, p. 141). And wage earners in that case receive "wages exceeding marginal productivity" (ibid.). The implication is that one can pull out workers from that sector without reducing the total output of the sector (or even increasing it in case of negative marginal productivity). 
9. Lewis believed in contrast to Asia that Africa had a labor shortage due to agricultural land availability. The constraint to growth in Africa was low agriculture productivity rather than manufacturing growth and required government intervention in agriculture (See Kanbur, 2016, p. 7).

10. A second MGI report (MGI, 2017b) released later the same year was much less pessimistic. It estimated labor displacement at $400 \mathrm{~m}$ jobs globally which would be offset by 555 million jobs created by increased labor demand.

11. There are further data sets of IMF (2017) and UNCTAD (2017) which we do not have access to at time of writing.

12. We may overemphasize the technical feasibility angle in this section given the data we use which leads us to an inverse relationship between automatability and per capita income. At the current cost of automation, there is a positive relationship and the curve may turn into an inverted $U$ as costs keeps falling and all jobs in developed countries have been automated, before eventually becoming negative; the question of course is how long away "eventually" is. Thus our assessment may be too pessimistic.

13. There is a significant $(p<0.05)$ positive correlation of industrial employment shares and automatability in HICs. This pattern is also found using the data of Arntz et al. (2016). It can similarly be observed in developing countries (non-HICs) in the McKinsey Global Institute (2017b) data where it is though not significant as data coverage is too limited.

\section{References}

Acemoglu, D., \& Autor, D. (2011). Skills, tasks and technologies: Implications for employment and earnings. In O. Ashenfelter \& D. Card (Eds.), Handbook of labor economics (Vol. 4B, pp. 1043-1171). Amsterdam: Elsevier.

Acemoglu, D., \& Restrepo, P. (2015). The race between machine and man: Implications of technology for growth, factor shares and employment. SSRN Electronic Journal. https://doi.org/10.2139/ssrn.2781320.

Acemoglu, D., \& Restrepo, P. (2017). Robots and jobs: Evidence from US labor markets (NBER Working Paper Series No. 23285). Cambridge, MA: NBER. Retrieved from http://www.nber.org/papers/w23285.

ADB (Asian Development Bank). (2018). Asian development outlook 2018: How technology affects jobs. Manila: ADB.

Arntz, M., Gregory, T., \& Zierahn, U. (2016). The risk of automation for jobs in OECD countries: A comparative analysis. OECD Social, Employment and Migration Working Papers, 2(189), 47-54.

Atkinson, A. B., \& Bourguignon, F. (2014). Introduction: Income distribution today. In A. B. Atkinson \& F. Bourguignon (Eds.), Handbook of income distribution, volume $2 A$ (pp. xvii-lxiv). Oxford and Amsterdam: Elsevier. 
Atkinson, R. D., \& Wu, J. (2017). False alarmism: Technological disruption and the U.S. labor market, 1850-2015. @Work Series. Retrieved from http:// www2.itif.org/2017-false-alarmism-technological-disruption.pdf.

Autor, D. H., \& Dorn, D. (2013). The growth of low-skill service jobs and the polarization of the US labor market. American Economic Review, 103(5), $1553-1597$.

Autor, D. H., Katz, L. F., \& Kearney, M. S. (2004). The polarization of the U.S. labor market. AEA Papers and Proceedings, 96(2), 189-194.

Avent, R. (2017). The wealth of humans: Work and its absence in the twenty-first century. London: Penguin Random House.

Barany, Z., \& Siegel, C. (2014). Job polarization and structural change. Retrieved from https://www.aeaweb.org/conference/2015/retrieve.php?pdfid=237.

Baumol, W. J. (1967). Macroeconomics of unbalanced growth: The anatomy of urban crisis. The American Economic Review, 57(3), 415-426.

Baumol, W. J., Blackman, B., \& Wolff, E. N. (1985). Unbalanced growth revisited: Asymptotic stagnancy and new evidence. The American Economic Review, 75(4), 806-817.

Bessen, J. (2016). How computer automation affects occupations: Technology, jobs, and skills (Law \& Economics Working Paper No. 15-49). Boston, MA. Retrieved from https://papers.ssrn.com/sol3/papers.cfm?abstract_id=2690435.

Castells, M. (2010). The rise of the network society: The information age: Economy, society, and culture. Hoboken, NJ: Wiley Blackwell.

Chandy, L. (2017). The future of work in the developing world: Brookings Blum roundtable 2016 post-conference report. Washington, DC: Brookings Institution.

Chang, J.-H., \& Huynh, P. (2016). ASEAN in transformation: The future of jobs at risk of automation (Bureau for Employers' Activities Working Paper No. 9). Bangkok. Retrieved from http://www.ilo.org/wcmsp5/groups/public/—ed_ dialogue/—act_emp/documents/publication/wcms_579554.pdf.

Christensen, C. (1997). The innovator's dilemma: When new technologies cause great firms to fail. Boston, MA: Harvard Business Review Press.

Clark, G. (2008). A farewell to alms: A brief economic history of the world. Princeton, NJ and Oxford: Princeton University Press.

Diao, X., McMillan, M., Rodrik, D., \& Kennedy, J. F. (2017). The recent growth boom in developing economies: A structural-change perspective (NBER Working Paper Series No. 23132). Cambridge, MA: NBER. Retrieved from http://www.nber.org/papers/w23132.

Eastwood, R., Kirsten, J., \& Lipton, M. (2007). Premature deagriculturalisation? Land inequality and rural dependency in Limpopo province, South Africa. The Journal of Development Studies, 42(8), 1325-1349.

Executive Office of the President of the United States. (2016). Preparing for the future of artificial intelligence. Washington, DC. Retrieved from https://obamawhitehouse.archives.gov/sites/default/files/whitehouse_ files/microsites/ostp/NSTC/preparing_for_the_future_of_ai.pdf. 
Frey, C. B., \& Osborne, M. A. (2013). The future of employment: How susceptible are jobs to computerisation? Oxford Martin School, University of Oxford Working Paper. University of Oxford, UK. Retrieved from https://www. oxfordmartin.ox.ac.uk/downloads/academic/future-of-employment.pdf.

Frey, C. B., Osborne, M. A., \& Holmes, C. (2016). Technology at work v2.0: The future is not what it used to be (Citi GPS: Global Perspectives \& Solutions). Oxford. Retrieved from http://www.oxfordmartin.ox.ac.uk/downloads/ reports/Citi_GPS_Technology_Work_2.pdf.

Frey, C. B., \& Rahbari, E. 2016. Do labor-saving technologies spell the death of jobs in the developing world (Paper prepared for the 2016 Brookings Blum Roundtable).

Goldin, C., \& Katz, L. F. (2007). The race between education and technology: The evolution of U.S. educational wage differentials, 1890 to 2005 (NBER Working Paper Series No. 12984). Cambridge, MA: NBER. Retrieved from http://www.nber.org/papers/wl2984.

Grace, K., Salvatier, J., Dafoe, A., Zhang, B., \& Evans, O. (2017). When will AI exceed human performance? Evidence from AI experts(arXiv No. 1705.08807v2). Retrieved from http://arxiv.org/abs/1705.08807.

Herrendorf, B., Rogerson, R., \& Valentinyi, A. (2014). Growth and structural transformation (NBER Working Paper Series No. 18996). Cambridge, MA: NBER. Retrieved from http://www.nber.org/papers/w18996.

IMF. (2017). World economic outlook, April 2017: Gaining momentum? Washington, DC: IMF. Retrieved from http://www.imf.org/en/Publications/ WEO/Issues/2017/04/04/world-economic-outlook-april-2017.

Kanbur, R. (2016). W. Arthur Lewis and the Roots of Ghanaian Economic Policy (Working Paper). Charles H. Dyson School of Applied Economics and Management Cornell University, Ithaca, New York.

Katz, L. F., \& Autor, D. H. (1999). Changes in the wage structure and earnings inequality. In O. Ashenfeher \& D. Card (Eds.), Handbook of labor economics (Vol. 3, pp. 1463-1555). Amsterdam: Elsevier.

Katz, L. F., \& Murphy, K. M. (2013). Changes in relative wages, 1963-1987: Supply and demand factors. The Quarterly Journal of Economics, 107(1), 35-78.

Lewis, W. A. (1954). Economic development with unlimited supplies of labour. The Manchester School of Economic and Social Studies, 22(2), 139-191.

Marx, K. (2012 [1867]). Das Kapital: A critique of political economy. Washington, DC: Regnery Publishing.

McKinsey Global Institute. (2017a). A future that works: Automation, employment, and productivity. Retrieved from https://www.mckinsey.com/ / media/McKinsey/Global\%20Themes/Digital\%20Disruption/Harnessing\%20 automation $\% 20$ for $\% 20 \mathrm{a} \% 20$ future $\% 20$ that $\% 20$ works /MGI-A-future-thatworks_Full-report.ashx. 
McKinsey Global Institute. (2017b). Jobs lost, jobs gained: Workforce transitions in a time of automation. Retrieved from https://www.mckinsey.com/ /media/ McKinsey/Global\%20Themes/Future\%20of\%20Organizations/What $\% 20$ the $\% 20$ future $\% 20$ of $\% 20$ work $\% 20$ will $\% 20$ mean $\% 20$ for $\% 20$ jobs $\% 20$ skills $\% 20$ and\%20wages/MGI-Jobs-Lost-Jobs-Gained-Report-December-6-2017.ashx.

McKinsey Global Institute. (2017c). Where machines could replace humans-And where they can't (yet). Retrieved from https://public.tableau.com/en-us/s/ gallery/where-machines-could-replace-humans.

McMillan, M. S., \& Rodrik, D. (2011). Globalization, structural change and productivity growth (NBER Working Paper Series No. 17143). Cambridge, MA: NBER. Retrieved from http://www.nber.org/papers/w17143.

Mishel, L., \& Bivens, J. (2017). The zombie robot argument lurches on: There is no evidence that automation leads to joblessness or inequality. Washington, DC: Economic Policy Institute. Retrieved from http://www.epi.org/files/pdf/ 126750.pdf.

Ngai, L. R., \& Pissarides, C. A. (2017). Structural change in a multi-sector model of growth. American Economic Review, 97(1), 429-443.

Office for National Statistics. (2013). 170 years of industrial change across England and Wales. Retrieved from http://webarchive.nationalarchives.gov. uk/20160106001413/http://www.ons.gov.uk/ons/rel/census/2011 census-analysis / 170-years-of-industry/170-years-of-industrial-changeponent. html.

PWC (PricewaterhouseCoopers). (2017). UK Economic Outlook.

Roine, J., \& Waldenström, D. (2014). Long-run trends in the distribution of income and wealth (IZA Discussion Paper No. 8157). Bonn: IZA. Retrieved from ftp.iza.org/dp8157.pdf.

Solow, R. M. (1956). A contribution to the theory of economic growth. The Quarterly Journal of Economics, 70(1), 65-94.

Solow, R. M. (1964). The nature and sources of unemployment in the United States. Stockholm: Almqvist and Wicksell.

Summers, L. H. (2013). Economic possibilities for our children: The 2013 Martin Feldstein lecture. NBER Reporter, 4, 4-6. Retrieved from http:// www.nber.org/reporter/2013number4/2013no4.pdf.

Tinbergen, J. (1974). Substitution of graduate by other labour. Kyklos, 27(2), 217-226.

Tinbergen, J. (1975). Substitution of academically trained by other manpower. Review of World Economics, 111(3), 466-476.

UNCTAD. (2017). Trade and development report 2017-Beyond austerity: Towards a global new deal. New York and Geneva: UNCTAD.

Wood, A. (2017). Variation in structural change around the world, 1985-2015: Patterns, causes, and implications (UNU-WIDER Working Paper). UNUWIDER: Helsinki. Retrieved from https://www.wider.unu.edu/sites/ default/files/wp2017-34.pdf. 
World Bank. (2016). World development report: Digital dividends. Washington, DC: World Bank.

World Bank. (2018). World development indicators. Retrieved from data.worldbank.org/data-catalog/world-development-indicators.

World Economic Forum. (2017). The future of jobs and skills in the Middle East and North Africa: Preparing the region for the fourth industrial revolution (Executive Briefing). Geneva: WEF.

Yusuf, S. (2017). Automation, AI, and the emerging economies. Center for Global Development Blog. Retrieved May 25, 2018, from https://www.cgdev. org/publication/automation-ai-and-emerging-economies.

Open Access This chapter is licensed under the terms of the Creative Commons Attribution 4.0 International License (http://creativecommons.org/licenses/ by $/ 4.0 /$ ), which permits use, sharing, adaptation, distribution and reproduction in any medium or format, as long as you give appropriate credit to the original author(s) and the source, provide a link to the Creative Commons license and indicate if changes were made.

The images or other third party material in this chapter are included in the chapter's Creative Commons license, unless indicated otherwise in a credit line to the material. If material is not included in the chapter's Creative Commons license and your intended use is not permitted by statutory regulation or exceeds the permitted use, you will need to obtain permission directly from the copyright holder.

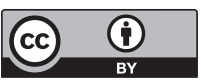

